\title{
THE EFFECT OF INTERPERSONAL INJUSTICE IN COUNTERPRODUCTIVE WORKING BEHAVIOR AND SELF-IDENTITY AS MODERATING VARIABLE
}

\author{
Sriwahyuni Ni Putu Eka, Student \\ Master's Study Program of Management, Faculty of Economics and Business, \\ University of Udayana, Bali, Indonesia \\ Supartha I Wayan Gede, Lecturer \\ Faculty of Economics and Business, University of Udayana, Bali, Indonesia
}

\begin{abstract}
Counterproductive work behavior by employees is a common problem for organizations. Counterproductive work behavior can be interpreted as intentional or unintentional behavior carried out by employess who are considered to violate the norm and have an impact on the welfare and members of the organization welfare. Interpersonal unfairness and employee self-identity are believed to influence counterproductive work behavior. Employee selfidentity is also believed to moderate the influence of interpersonal unfairness on counterproductive work behavior. This research was conducted on the employees of the Badung Regency Land Agency with the aim to analyze the effect of interpersonal unfairness on counterproductive work behavior moderated by employee self-identity. The number of samples taken was 112 respondents with a simple random sampling method, where individuals were chosen as a sample of all employees of the Badung Regency Land Agency conducted randomly, totally on the basis of the opportunity factor. Data analysis techniques used in this study are descriptive statistical analysis and moderating regression analysis (MRA). The results showed that: 1) linterpersonal unfairness has no effect on counterproductive work behavior, 2) The employee's self-identity influences counterproductive work behavior or hypothesis is accepted. 3) Self-identity moderates the influence of interpersonal unfairness on counterproductive work behavior or accepted hypothesis.
\end{abstract}

\section{KEY WORDS}

Interpersonal unfairness, counterproductive work behavior, employee self-identity.

These past few years many researchers have focused their research on positive work behavior of employees, so that research that focuses on negative work behavior of employees is relatively less attention (Syaebani and Sobri, 2013). Research that emphasizes negative employee behavior should also be considered as well as positive work behavior. Negative work behavior can be a cost for the organization and trigger other employees to behave negatively. Jones (2009) and Peterson (2002) describe the results of their research that counterproductive work behavior is considered to have negative consequences that can adversely affect the organization. The negative consequences can be in the form of economic losses as well as social and psychological impacts for the organization and employees in the organization. Examples of economic losses from counterproductive work behavior are presented by Christian and Ellis (2011) that estimated losses in the United States caused by employee stealing in a year can reach more than $\$ 40$ billion, and losses caused by absenteeism are estimated to reach around $\$ 30$ billion. In other studies it was also reported that in aggregate economic losses each year caused by counterproductive work behavior were estimated at $\$ 200$ billion in the United States (Penney and Spector, 2002), and around $\$ 600$ billion in the United Kingdom (Ferris, et al., 2009). Examples of counterproductive work behavior losses in the form of social and psychological impacts are presented in Smithikrai's research (2008) that 60 percent of employees in Thailand who are victims of deviations from other employees' work behaviors experience a decrease in enthusiasm in completing work. The Productivity Commission (2010) also reports that an 
average of 24 per cent of employees in Australia have become unproductive in completing work due to mental stress as a result of harassment and intimidation received related to counterproductive work behavior.

Counterproductive work behavior is a deviant behavior performed by employees in an organization. According to Kelloway et al. (2010), counterproductive behavior can be a form of protest that indicates employee dissatisfaction with the company. Counterproductive work behavior is not all a form of protest behavior, but behavior that can be a means to protest injustice. Peterson (2002) states that the growth of deviant behavior in the work is due to unfair behavior in the workplace. Hakim et al., (2006) also stated that the justice dimension is a predictor of the results of some specific forms of deviations in the workplace. Counterproductive actions can come in various forms such as stealing, doing sloppy work, delaying work, or disobeying work hours. Actions like this will certainly disrupt work productivity, both in terms of quality and quantity. Therefore, it is very important for a manager to understand employee behavior. Managers face problems all the time related to human behavior (Wibowo, 2014: 4). A manager needs to understand about the causes of counterproductive work behavior, so he can know the preventive and repressive efforts to overcome them. According to Martinko et al. (2002), counterproductive work behavior is largely due to: (1) individual differences factors, such as personality characteristics and demographic characteristics; (2) situational factors, such as organizational justice and leadership style.

Regarding organizational justice, Henle (2005) considers that employee perceptions about the sense of fairness received in an organizational environment can be an important element in making a decision to make a deviation or not. Sense of injustice felt by employees, can lead to dissatisfaction. Counterproductive work behavior is shrouded and often overlooked in organizations, but this behavior has a large impact on productivity (Thomas, 2012). In a research by Nurfiani and Handoyo (2013), it is stated that counterproductive work behavior has a relationship with distributive justice, but the results of the research show that the level of relations is moderate. Counterproductive work behavior can occur in all types of organizations, but Alias et al. (2013) states that counterproductive work behavior is more common in public sector organizations compared to private sector organizations. Furthermore Dick and Rayner (2013) explain the indications of counterproductive work behavior, such as absenteeism of employees without permission, intimidation at work, and violations of organizational rules, tend to be higher in public sector organizations than employees working in private sector organizations. In general, counterproductive work behavior that occurs in public sector organizations, including those who adhere to the bureaucratic system, is often done in the form of employee indiscipline and some other forms of deviation of work behavior. Ahearne and Jelinek (2006) explained that the bureaucratic system in an organization can be one of the causes of counterproductive work behavior for employees. Counterproductive work behavior that occurs among government employees in Indonesia is certainly closely related to the discipline of Civil Servants. Government Regulation of the Republic of Indonesia which regulates the discipline of Civil Servants namely Government Regulation number 53 of 2010. In Government Regulation of the Republic of Indonesia Number 53 of 2010, it is stated that disciplinary violations committed by Civil Servants (PNS) will be sentenced according to level and type discipline. Nevertheless, every civil servant who violates the rules of discipline can still make administrative efforts as a form of objection to dissatisfaction with the sentence that has been decided and handed down to the relevant civil servant. The existence of these administrative efforts can certainly cause disciplinary procedures to be more relaxed, so that triggers many civil servants in Indonesia who are involved in counterproductive work behavior.

During this time public opinion and image of convoluted public services, extortion and unclear time and its resolution become the actual issues that continue to emerge that must be sought solutions and solutions immediately. This condition is due to the quality of the system and management in public services organized by the government that have not been optimal and the integrity, ethos, and culture of the apparatus that are not developed (Junaidi, 
2014). Considering that the main function of the government is to serve the community, improvement in the quality of services absolutely must continue. The community as service users has an important role in providing feedback for improving the quality of services they obtain. endahnya quality of public services can be caused by the quality of human resources that have not been optimal. Quality of Human Resources (HR) is the main key to the success of public services. Low human resources directly adversely affect the quality of public services. If public services are organized arbitrarily, it will be difficult to create good governance.

This study refers to previous studies conducted by Yang et al. (2013) that is, examining the role of self-identity in moderating the relationship of interpersonal injustice and counterproductive work behavior with 361 employees of the Chinese aviation industry as a research sample. The results of the study stated that the influence of interpersonal injustice with counterproductive work behavior can be moderated by the role of self-identity. Relational identity and high collective identity can weaken the influence of interpersonal injustice on counterproductive work behavior. Thus, self-identity support has a role in moderating the influence of interpersonal injustice on counterproductive work behavior. The work behavior of political irregularities at the Badung Regency Land Agency can be explained for example such as the presence of employees providing information about land data which are state documents that are confidential which should not be shared with other parties that are not determined by statutory regulations. This certainly can affect office performance, land disputes due to misuse of land data and information.

While the deviation of individual aggression behavior (personal aggression) at the Badung Regency Land Agency, can be shown by the existence of some employees who ignore the instructions of their superiors, even do not establish good relations with superiors. Another example given by the Head of Public Affairs and Civil Service is that there are still employees who say harshly to other colleagues so that they offend others. Counterproductive work behaviors can be transmitted from one employee to another, especially if the employee feels that interpersonal injustice has occurred in his organization. Therefore it is very important to conduct research on the effect of interpersonal injustice on the counterproductive work behavior of employees at the Badung Regency Land Agency by taking into account the employee's self-identification factor. This is because the level of volume of activities at the Badung Regency Land Agency which of course is in dire need of competent human resources and able to guarantee services in the land sector properly.

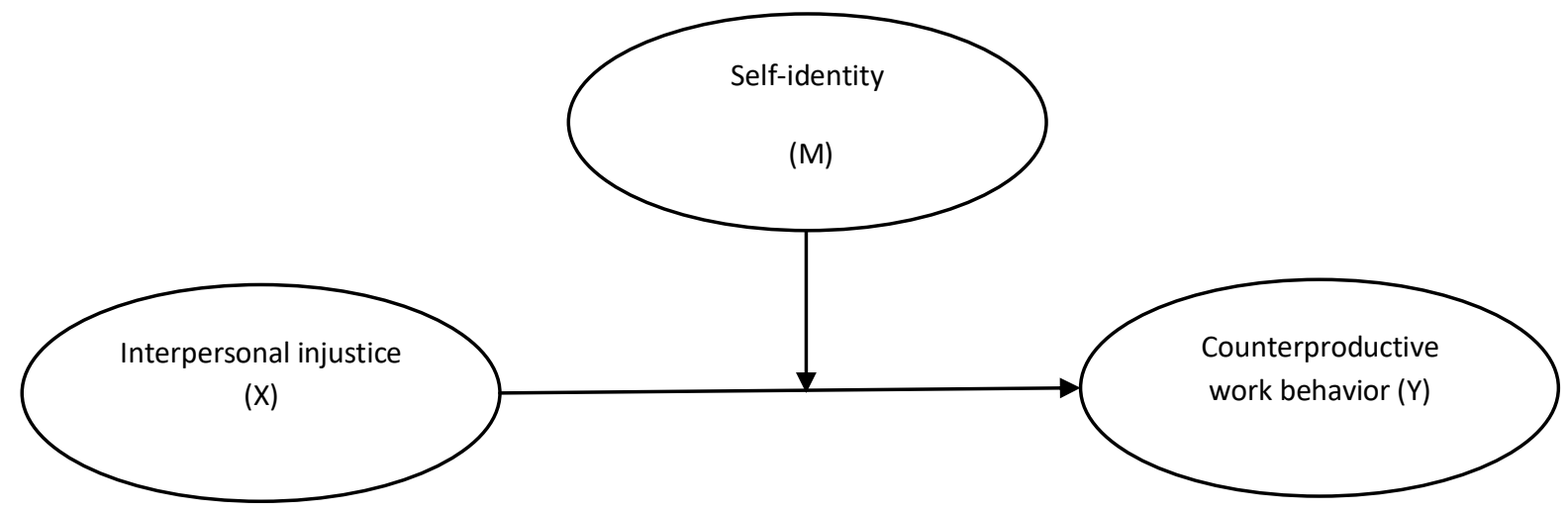

Figure 1 - Conceptual Framework

Hypotheses:

- H1: Interpersonal Injustice has a significant effect on Counter-productive Work Behavior;

- H2: Employee self-identity has a significant effect on counter-productive work behavior;

- H3: Employee self-identity moderates the influence of interpersonal injustice on counter-productive work behavior. 


\section{METHODS OF RESEARCH}

This study measures and analyzes the relationship of interpersonal injustice with counterproductive work behavior with employee self-identity as a moderating variable. This research took place at the Badung Regency Land Agency. Reasons for choosing the Badung Regency Land Agency as a research location, in order to be able to find out the relationship of interpersonal injustice with counterproductive work behavior that is moderated by employee self-identity. The population in this study was chosen by all staff at the Badung Regency Land Agency as many as 156 people because the staff had more potential to engage in counter-productive work behavior than officials who would certainly be an example for their staff. Determination of the number of samples is calculated by the Slovin Formula (Umar, 2004) which is obtained the number of samples in this study as many as 112 employees. Hypothesis testing in this study uses regression analysis with moderating variables (Moderating Regression Analysis).

\section{RESULTS AND DISCUSSION} results:

MRA analysis in this study was processed using SPSS, so as to obtain the following

Table 1 - Result of Moderating Regression Analysis (MRA) test

\begin{tabular}{|c|c|c|c|c|c|}
\hline \multicolumn{6}{|l|}{ Coefficients $^{a}$} \\
\hline \multirow[b]{2}{*}{ Model } & \multicolumn{5}{|c|}{\begin{tabular}{|l|l|} 
Unstandardized Coefficients & Standardized Coefficients
\end{tabular}} \\
\hline & $\mathrm{B}$ & Std. Error & Beta & t & Sig. \\
\hline 1 (Constant) & 6,507 & 1,429 & & 4,552 &, 000 \\
\hline Interpersonal Injustice &,- 412 &, 339 &,- 463 & $-1,216$ & 227 \\
\hline Employee Identity & $-1,238$ & 351 & $-1,434$ & $-3,524$ &, 001 \\
\hline Interpersonal Injustice * Employee Identity & 265 & 083 & 1,768 & 3,183 &, 002 \\
\hline
\end{tabular}

a. Dependent Variable: Counterproductive work behavior

Based on the table above, the regression equations resulting from Moderating Regression Analysis (MRA) are as follows:

$$
\begin{gathered}
Y=\beta_{0}+\beta_{1} X+\beta_{2} M+\beta_{3} X M \\
Y=6,507-0,412 X-1,238 M+0,265 X M
\end{gathered}
$$

Effects of Interpersonal Injustice on Counterproductive Work Behavior. Based on statistical calculations, we found out that the significance value of the coefficient of 0.210 is greater than the level of mistrust of 5 percent or $\alpha=(0.05)$, and the $t$ value is $1.216<$ from the $\mathrm{t}$ table value of 1.9813. This interpersonal injustice that has no effect on counterproductive behavior shows that although there are employees who feel unfair, let down, treated disrespectfully by superiors or coworkers, the employee still shows productive performance. This could be due to the professional attitude shown for the progress of the organization or due to other factors. In addition, the negative sign shows that if interpersonal injustice increases, then counterproductive work behavior will decrease and vice versa if interpersonal injustice decreases then counterproductive work behavior will increase. This could have happened because of a deep feeling of disappointment felt by certain employees and the attitude of the ignorant attitude in a situation where when the boss has corrected the mistakes that are trying to be fair, respectful, and respectful, but the employee still feels disappointed and continues to deviate behavior like arriving late, leaving early, and other deviant behavior. These results indicate that the circumstances that occur are not in line with the theory put forward by Kelloway et al (2010), that counter productive work behavior will be a means of protesting an injustice felt by employees or employees both individually and collectively. This result is also not in line with the theory put forward by Masterson et al (2000); Teklean and Taylor 2005) which said that injustices felt by employees would be shown by negative reactions. 
The Influence of Employee Identity on Counterproductive Work Behavior. The results of hypothesis testing indicate that the significance value of the coefficient of 0.001 is smaller than the level of distrust of 5 percent or $\alpha=(0.05)$. This shows that if the employee's selfidentity has an influence on counterproductive work behavior. Employee identity will affect employee performance behavior, this depends on the positive or negative influence of employee personal. In addition, the results of this test also show that the t-value is -3.524 , this negative sign indicates that if the employee's self-identity rises then counterproductive work behavior decreases. Vice versa, if the employee's self-identity decreases, counterproductive work behavior rises. Employees who have a patient and guiding nature will influence other employees to make changes that were previously counterproductive to productive attitudes. The influence of relational self-concepts such as bonding friend relations will provide a positive influence. Friends who have counterproductive attitudes will gradually become more productive thanks to friends who continue to provide input, and support to be better. This trait is a relational self-concept which was also put forward by (Brewer and Gardner, 1996; Hazan and Shaver, 1994; Reis and Shaver, 1988).

The Role of Employee's Self-Identity in Moderating the Effect of Interpersonal Injustice $\left(X{ }^{*} M\right)$ on Counterproductive Work Behavior. Based on the results of hypothesis testing shows that the significance value of the coefficient of 0.002 is smaller than the level of distrust of 5 percent or $\alpha=(0.05)$. Anova test results show that the F-calculated result of 53.279 is greater than the $F$ table of 3.0773 ( $F$-count 53.279> F-table of 3.0773) and the significance value of 0.000 . This means that simultaneously interpersonal injustice and selfidentity variables influence counterproductive work behavior. The data processing results obtained Adjusted $\mathrm{R}$ Square value of 0.586 . This shows that counterproductive work behavior is influenced by interpersonal injustice and employee self-identity as a moderating variable of 58.6 percent, while the rest is influenced by other factors. Self-identity is an attitude or trait that is owned by employees in dealing with every moment at work. The concept of self whether positive or negative will have an impact on personal or group self or colleagues. Positive self-identity will have a positive impact, which is productive behavior. This productive behavior such as arriving on time, completing work on time, using office facilities appropriately, and leaving work at his time. Vice versa, negative self-identity will worsen counterproductive performance, whether it's fair or not, which is representative of the attitude of superiors or coworkers will form employee identity. Like employees who initially have a good attitude, competent, full of enthusiasm will experience a negative attitude if the boss or coworkers who do not respect and accept their opinions. Thus, the Badung Regency Land Agency employee considers that self-identity is formed from the attitude of superiors or colleagues who inevitably results in a productive or counterproductive attitude. This result is also in line with the results of the MRA regression which says that self-identity which is a moderating variable is able to strengthen or weaken the influence of interpersonal injustice on counterproductive work behavior.

\section{CONCLUSION AND SUGGESTIONS}

Based on the results of the analysis and discussion carried out previously, the conclusion that can be drawn is that interpersonal injustice does not affect counterproductive work behavior at the Badung Regency Land Agency. Employee identity has a negative and significant effect on counterproductive work behavior at the Badung Regency Land Agency. If the employee's self-identity is improved, then counterproductive work behavior will decrease. Conversely, if employee self-identity decreases, counterproductive work behavior increases. Employee identity variable moderates the effect of interpersonal injustice on counterproductive work behavior at the Badung Regency Land Agency. Interpersonal injustice and employee self-identity $(X * M)$ have a positive and significant effect on counterproductive work behavior. If interpersonal injustice is moderated by employee selfidentity, then counterproductive work behavior will increase. Conversely, if interpersonal injustice is moderated by employee self-identity decreases, then counterproductive work behavior decreases. 
Based on the results of the descriptive responses of respondents in this study, it is recommended that the following suggestions be given to relevant agencies to foster mutual respect and respect between leaders and employees or among employees in order to create a harmonious relationship within the agency. Professionalism needs to be upheld, but mutual respect and respect must also not be forgotten. This attitude of mutual respect and respect can be reflected in the ease with which employees give their opinions or aspirations, but it is also necessary to respect and respect the roles of leaders and employees in the agency.

It is expected that the relevant agencies implement balanced rewards and punishments. Leaders are expected to give appreciation to employees who have obeyed the rules and tried to show improved performance. Praising and giving rewards to employees has a good effect not only on related employees but on all parts because it shows that leaders pay attention to their hard work so that they themselves will be motivated, morale increases and contribute more in efforts to achieve agency goals. Instead, apply proper punishment to employees who violate regulations to suppress counterproductive work behavior. It is expected that the relevant agencies schedule specific training as a forum for capacity building and self-identification of employees with appropriate timing and type of training. It is expected that the agency conducts occasional bonding events outside the office in an effort to foster good ties or relational relations between superiors or fellow colleagues such as outbound or gathering and other activities that involve all members in the office. It is expected that future researchers will be able to dig deeper into factors and other variables that can influence counterproductive work behavior not examined in this study such as the role of supervisor control, reward and punishment, work stress, organizational commitment, emotional intelligence or other independent variables.

\section{REFERENCES}

1. Ahearne, M., dan Jelinek, R. 2006. The Enemy Within: Examining Salesperson Deviance and Its Determinants. Journal of Personal Selling and Sales Management. Vol. 26 (4), 327-344.

2. Alias, M., Rasdi, R.M., dan Ismail M. 2013. Predictors of Workplace Deviant Behaviour: HRD Agenda for Malaysian Suport Personel. European Journal of Training and Development. Vol.37 (2) : 161-182.

3. Brewer, M. B., \& Gardner, W.1996. Who is this "we"? Levels of collective identity and self-representations. Journal of Personality and Social Psychology, Vol. 71, 83-93

4. Christian, M. S. dan Ellis, A. P. J. 2011. Examining the Effects of Sleep Depravation on Workplace Deviance: A Self-Regulatory Perspective. Academy of Management Journal. Vol. 54 (5): 913-934.

5. Dick, G.P.M. dan Rayner, C. 2013. Negative Interpersonal Behavior at Work: An Evidence Based Classification of Workplace Bullying. International Journal of Psychology and Behavioural Science. Vol.3 (4) : 95-108.

6. Ferris, D.L., Brown, D.J., dan Heller, D. 2009. Organizational Supports and Workplace Deviance: The Mediating Role of Organization-Based-Self-Esteem. Organizational Behavior and Human Decision Processes. Vol.108: 279-286.

7. Ferris, D.L., Brown, D.J., Lian, H., and Keeping, L.M. 2009. When does self-esteem relate to deviant behavior? The role of contingencies of self-worth. The Journal of Applied Psychology. Vol. 94(5), 1345-1353.

8. Hazan, C. dan Shaver, P.R. 1994. Attachment as an Organizational Framework for Research on Close Relationships. Psycho-logical Inquiry. Vol. 5, pp: 1-22.

9. Henle, C. 2005. Predicting Workplace Deviance from the Interaction Between Organizational Justice and Personality. Journal of Managerial Issues. Vol.17, pp.247264.

10. Jones, A.D. 2009. Getting Even with One's Supervisor and One's Organization: Relationship Among Types of Injustice, Desires for Revenge and Counterproductive Work Behaviours. Journal of Applied Psychology. Vol. 92 (1), 228-238. 
11. Junaidi, M. 2010. Penyelenggaraan Pelayanan Administrasi Terpadu Kecamatan (PATEN) di Kecamatan Kota Sumenep. Top 99 Inovasi Pelayanan Publik Indonesia Tahun 2014. Jakarta: Kementerian Pendayagunaan Aparatur Negara dan Reformasi Birokrasi.

12. Kelloway, E.K., Lori Francis, Matthew Prosser, James E. Cameron. 2010. Counterproductive Work Behavior as Protest, Journal of Human Resource Management Review, Vol. 20, 18-25.

13. Martinko, M.J., Gundlach, M.J., dan Douglas, S.C. 2002. Toward an Integrative Theory of Counterproductive Workplace Behaviour: A Causal Reasning Perspective. International Journal of Selection and Assessment. Vol. $10: 36-50$.

14. Masterson, S.S., Lewis, K., Goldman, B.M., dan Taylor, M.S. 2000. Integrating Justice and Social Exchange: The Differing Effects of Fair Procedures and Treatment On Work Realtionships. Academy of Management Journal. Vol. 43 (4): 738-748.

15. Nurfiani A. dan Handoyo S. 2013. Hubungan antara Keadilan Distributif dan Perilaku Kerja Kontraproduktif dengan mengontrol Leader Member Exchange.Jurnal Psikologi Industri dan Organisasi, Fakultas Psikologi Universitas Airlangga Surabaya, Vol.02 no.03.

16. Penney, L.M. dan Spector, P.E. 2002. Narcissism and Counterprodutive Work Behavior: Do Bigger Egos Mean Bigger Problems?. International Journal of Selection and Assesment. Vol. 10: 126-134.

17. Peterson, D.K. 2002. Deviant Workplace Behavior and the Organization's Ethical Climate. Journal of Business and Psychology. Vol.17 (1): 47-61.

18. Productivity Commission. 2010. Performance Benchmarking of Australian Business Regulation: Occupational Helath and Safety. Research Report. Canberra.

19. Reis, H.T. dan Shaver, P. 1988. Intimacy as an Interpersonal Process. Handbook of Personal Relationships: Theory, Research and Interventions (1st ed, pp. 367-389). Chichester, England: Wiley.

20. Republik Indonesia. 2010. Peraturan Pemerintah Nomor 53 Tahun 2010 tentang Disiplin Pegawai Negeri Sipil. Lembaran Negara Republik Indonesia Tahun 2010 Nomor 74. Jakarta: Sekretariat Negara.

21. Smithikrai, C. 2008. Moderating Effect of Situasional Strength on the Relationship Between Personality Traits and Counterproductive Work Behaviour. Asian Journal of Social Psychology. Vol.11: 253-263.

22. Syaebani, M.I., dan Sobri, R. R. 2013. Relationship Between Organizational Justice Peception and Engagement in Deviant Workplace Behavior. The South East Asian Journal of Management. Vol.5 (1), 37-50.

23. Thomas, J. 2012. Counterproductive Work Behavior, Living in Wonderland, White Paper Publisher, New Zealand.

24. Wibowo.2014. Perilaku Dalam Organisasi. Jakarta.PT. Raja Grafindo Persada. 